\title{
Socket sealing using pedicle subepithelial connective tissue graft with tunneling in maxillary esthetic zone: Case reports
}

\author{
Ju-Eun Bae, Yong-Gun Kim, Jin-Woo Park, Jae-Mok Lee, Jo-Young Suh* \\ Department of Periodontology, School of Dentistry, Kyungpook National University, Daegu, Korea
}

\begin{abstract}
Reports have it that horizontal and vertical loss of the ridge happens during 6 months after tooth extraction. So valuable ridge preservation techniques are often necessary in the maxillary anterior areas. Maintaining and/or increasing blood supply and stability is essential to graft survival. The objective of this study was to determine the effect on extraction socket seal of pedicle subepithelial connective tissue graft with tunneling on maxillary esthetic zone through healing state for 8 weeks.
\end{abstract}

Key Words: Connective tissue graft, Maxilla, Palatal tunneling, Pedicled flap

(c) This is an open-access article distributed under the terms of the Creative Commons Attribution Non-Commercial License (http://creativecommons.org/licenses/by-nc/4.0) which permits unrestricted noncommercial use, distribution, and reproduction in any medium, provided the original work is properly cited.

\section{서 론}

치아의 발치는 외상이나 파절, 근단병소, 치주병소 등에 기인 한다. 발치 후 치조돌기는 치아 의존적 조직이므로[1] 하방골의 체적변화가 일어나며, 주변 연조직의 구조적 변화를 일으키게 된다. 몇몇 리뷰논문에 따르면 발치 6개월 후 수평적 골소실은 $3.8 \mathrm{~mm}$, 수직적 골소실은 $1.24 \mathrm{~mm}$ 로 보고되었다[2,3].

발치 후 골소실은 특히 치조제 협측에서 일어나며 상악 협측 판의 골소실은 임플란트와 최종보철물의 질과 심미에 영향을 미친다. 발치 후 치조제보존술은 골소실을 줄이고 안정적인 치 조제 부피와 인접 연조직 높이를 유지하고 임플란트의 심미적 인 결과를 증진시킨다고 보고되었다[4]. 발치 후 연조직과 경조 직 체적을 유지하게 되면, 유지된 체적은 임플란트 식립 시 술 식을 단순하게 하며, 심미적인 연조직을 형성하는데 중요하다. Lekovic 등[5,6]은 발치와 입구가 상피화되기 전까지 상피 침투
를 막고 이식재를 보존하기 위해 일차피개가 필요하다고 주장 하였으며, 특히 자가조직 이식술을 사용하면 각화조직을 증가 시키고 심미적 결과를 가져온다고 보고되고 있다[7-9].

발치와 일차피개를 위해 자가조직 이식술의 다양한 방법들이 보고되어 왔다. 구개부 부분층 회전 판막(rotated split palatal flap)이나 구개부 전층 회전 판막(rotated full-thickness flap) 과 골이식을 사용하여 즉시 임플란트 식립 시 협측골 열개를 처 치하였다[10]. 또한 즉시식립 임플란트의 일차피개를 위해 골 이식 시행 여부와 관련 없이 L-모양의 판막을 시행하여 6-8개 월의 치유기간 후 수여부의 완벽한 폐쇄가 가능하도록 하였다 [11]. 근심부는 절개하지 않은 상태로 구개부 상피하 결체조직 을 이용하여 다양한 상악 결손부를 처치하기 위해 회전시킨 방 법도 사용되었다[12]. 골막이 붙은 채로 젖혀 수직적 연조직 증 대를 이룬 Matthews[13] 방법도 보고되었다. 이러한 유경조직 을 이용한 방법은 후방의 구개부 혈관이 잘려도 구개부 점막의

Received September 13, 2018; Revised November 14, 2018; Accepted November 21, 2018

Corresponding author: Jo-Young Suh, Department of Periodontology, School of Dentistry, Kyungpook National University, 2177 Dalgubeoldaero, Jung-gu, Daegu 41940, Korea.

Tel: +82-53-600-7521, Fax: +82-53-427-3263, E-mail: jysuh@knu.ac.kr

Copyright $\odot$ 2018, Oral Biology Research Institute 
혈액공급이 가능하여 연조직 이식의 활용성이 높고 공여부와 수여부의 창상치유가 개선된다는 장점을 가진다. 하지만 단점 으로는 술 후 합병증인 부분적 괴사가 $1.9 \%-26.0 \%$ 까지 보고되 었다는 점이다[10,12,14].

최근 Romanos 등[15]은 유경조직 이식술을 터널과 함께 시 행하여 혈액공급과 안정성을 증가시키는 방법을 보고하였다. 구치부에서 해당치아 원심부에 이르도록 절개하고, 근심부는 절개를 가하지 않은 채 $1.5 \mathrm{~mm}$ 두께의 상피하 유경조직을 채득 하여 결손부 원심부 치아 구개측 점막에 형성한 터널을 통해 삽 입, 발치와를 피개하는 방법으로 결손부에 적용시키는 것이다 [15].

본 연구에서는 심미 영역에 관여하는 상악 중절치, 측절치, 제 1 소구치를 대상으로 하여, 발치 후 치조제 보존 술식으로 상피 하 결합조직 이식술과 함께 터널을 형성하여 발치와 폐쇄를 하 였을 때 골 높이와 너비의 변화, 환자의 통증 양상에 관하여 살 펴보았다.

\section{증례보고}

\section{술 전 검사와 수술 부위 평가}

발치를 시행하기 전 구강 내 사진과 방사선 사진을 촬영하고 치주낭 탐침 깊이를 측정하였다. Elian 등[16]은 발치와 형태로 type 1-3으로 분류하였다. Type 1은 협측 연조직과 골이 발치 전 백악법랑질 경계 수준이며 발치 후 원상태를 보존하는 경우, type 2 는 협측 연조직은 존재하나 발치 후 협측골 소실이 관찰 되고, type 3은 협측 연조직과 골이 발치 후 현저하게 감소되는 경우이다. Type 1은 치료가 쉽고 예지성이 있으며 대부분 임플 란트 식립 시 가장 훌륭한 심미성을 보이게 되고, type 3은 연조 직 퇴축과 협측골의 상실로 인하여 치료가 어렵고 연조직 증대 가 필요하다. Type 2나 3의 경우 발치 후 협측골 상실이 예측되 기 때문에 경조직과 연조직을 보존할 수 있는 치조제 보존술이 필요하다.

이번 연구에서는 경조직이나 연조직 상실이 예상되는 Elian 등[16]의 분류 type 2,3 경우에 한하여 경조직, 연조직 이식술 의 시행이 계획되었다. 또한 치은 biotype이 얇을수록 치은 퇴 축이 더 잘 될 수 있으므로, 치은 biotype도 미리 파악하였다. 이 는 Claffey와 Shanley[17]의 분류에 따라 치은 변연 하방 $2 \mathrm{~mm}$ 협측 중앙부에서 탐침을 관통시켜 계측하여, $1.5 \mathrm{~mm}$ 미만일 경 우 얇은 치은으로, $2 \mathrm{~mm}$ 이상일 경우 두꺼운 치은으로 분류하 였다.

\section{임상적, 방사선학적 소견}

환자 1 은 40세 남자로 전신질환은 없었으며, 방사선 촬영 결 과 상악 좌측 측절치의 치주근단 병소가 관찰되어(Fig. 1) 발치 후 임플란트 식립을 계획하였다. 해당 치아의 탐침 결과, 탐침 깊이는 협측 근심부터 $11,10,10 \mathrm{~mm}$ 였으며 구개측 근심부부 터 $14,3,5 \mathrm{~mm}$ 로 관찰되었다. 경조직, 연조직 평가 후 협측골 상실과 연조직 퇴축이 존재하는 발치와 type 3 으로 진단되었으 며, $1 \mathrm{~mm}$ 의 thin biotype으로 발치 후 골흡수와 치은퇴축이 예 상되었다.

환자 2는 56세 남자로 전신질환은 없었으며, 방사선 촬영 결 과 상악 우측 제1소구치의 치근파절이 관찰되어(Fig. 2) 발치 후 임플란트 식립을 계획하였다. 해당 치아의 탐침 결과 탐침 깊이 는 협측 근심부부터 $7,5,5 \mathrm{~mm}$ 였으며 구개측 근심부부터 11 , $5,5 \mathrm{~mm}$ 로 관찰되었다. 경조직, 연조직 평가 후 협측골 상실 과 연조직 퇴축이 존재하는 발치와 type 2로 진단되었으며, 1.4 $\mathrm{mm}$ 의 thin biotype으로 발치 후 골흡수와 치은퇴축이 예상되 었다.

환자 3은 47세 남자로 전신질환은 없었으며, 방사선 촬영 결 과 상악 우측 중절치의 치근파절이 관찰되어(Fig. 3) 발치 후 임 플란트 식립을 계획하였다. 해당 치아의 탐침 결과 탐침 깊이는 협측 근심부부터 $3,3,4 \mathrm{~mm}$ 였으며 구개측 근심부부터 18,7 , $3 \mathrm{~mm}$ 로 관찰되었다. 경조직, 연조직 평가 후 협측골 상실과 연 조직 퇴축이 존재하는 발치와 type 3 로 진단되었으며, $1 \mathrm{~mm}$ 의 thin biotype으로 발치 후 골흡수와 치은퇴축이 예상되었다.

세 증례 모두 후속 조치로 임플란트 식립이 계획되어 있어 경, 연조직 증대가 필요하였다. 치료는 경조직 처치로 Bio-Oss (Geistlich Pharma AG, Wolhusen, Switzerland)을 이용한 발
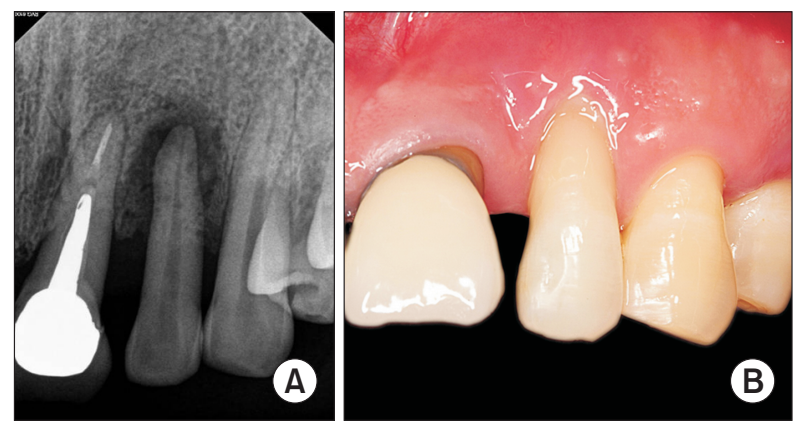

Fig. 1. (A) Initial intraoral radiograph of patient 1 , showing severe bone resorption of maxillary left lateral incisor. The tooth was periodontally hopeless and thus extraction and implantation were planned. (B) Initial intraoral view of patient 1 . After the evaluation of soft and hard tissue, it was diagnosed as type 3 with buccal bone loss and soft tissue recession. Soft tissue augmentation was required because of thin biotype (1 mm gingival thickness). 

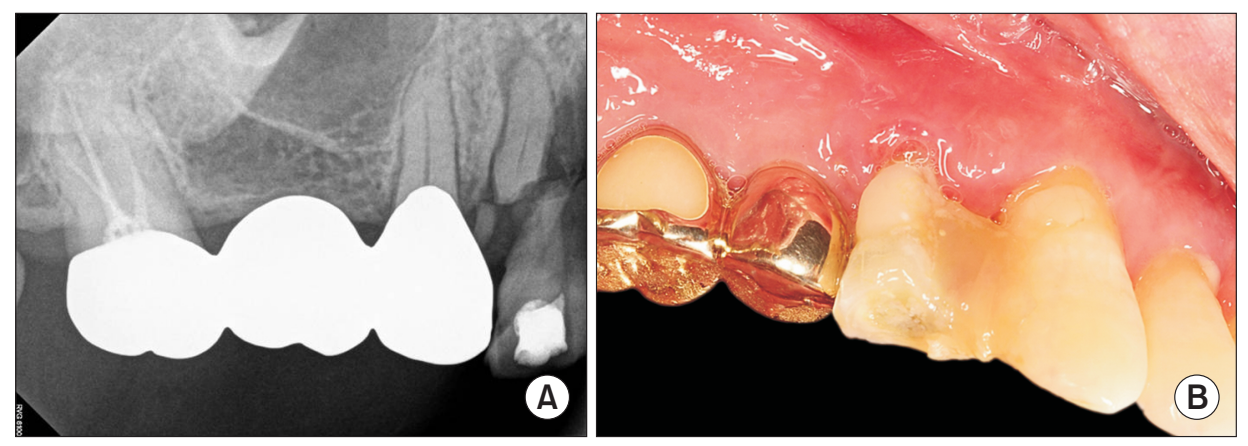

Fig. 2. (A) Initial intraoral radiograph of patient 2, showing severe bone resorption and root fracture of maxillary right first premolar. The tooth was periodontally hopeless and thus extraction and implantation were planned. (B) Initial intraoral view of patient 2. It was diagnosed as type 2 with buccal bone loss but with no soft tissue recession. Soft tissue augmentation was required because of thin biotype (1.4 mm gingival thickness).
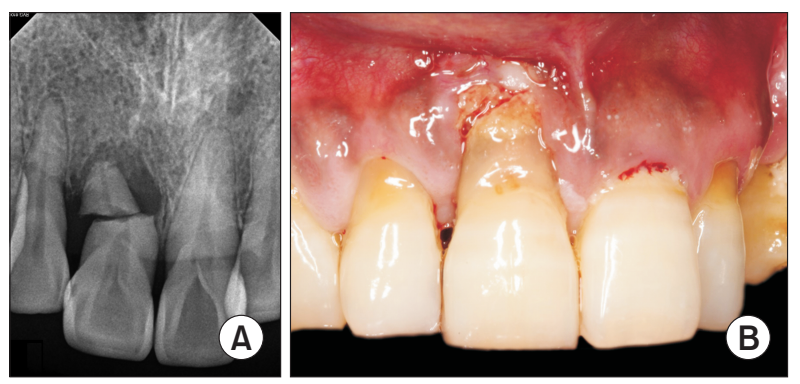

Fig. 3. (A) Initial intraoral radiographic view of patient 3 , showing severe bone resorption of maxillary right central incisor. The tooth was periodontally hopeless and thus extraction and implantation were planned. (B) Initial intraoral view of patient 3. It was diagnosed as Type 3 with buccal bone loss and soft tissue recession. Soft tissue augmentation was required because of thin biotype (1 $\mathrm{mm}$ gingival thickness).

치와 보존술, 연조직 처치로는 터널을 이용한 상피하 결체조직 이식술이 계획되었다.

\section{치아 발거 및 경조직, 연조직 이식술}

세 명의 환자에서 국소마취 후 치조골까지 조직을 절단하기 위해 치주낭 내로 periotome을 이용하여 최대한 발치와에 손상 이 없도록 비외상적 발치를 시행하고 해당악 제1대구치에서 해 당 치아 원심부에 이르기까지 구개측 상피하 결체조직을 유경 조직으로 채취하였다. Liu와 Weisgold[18]의 분류에 따라 하나 의 절개선에 원심부 수직절개를 가하여 술식의 편의성을 높였 다. 발치와의 구개측 원심부에서 터널을 orban knife로 형성하 고 유경-상피하 결체조직을 전진시켜 터널 안으로 삽입한 후, 협측 치은을 골막과 분리(undermining)한 후 협측 치은 하방 3 $\mathrm{mm}$ 까지 삽입하였다. Bio-Oss를 발치와 벽까지 다 채우고 5-0 surgifit (AILEE Co., Busan, Korea)로 협측 치은와 유경-상피 하 결체조직을 교차누상봉합법으로 봉합하고 안정을 위해 필요 한 경우 부가적으로 단속봉합을 시행하였다. 구개측 부위는 4-0 nylon (AILEE CO.)으로 교차누상봉합과 단속봉합을 시행하였 다(Fig. 4).

\section{스텐트 제작 및 치조제 보존술 측정 방법}

인상을 채득하고 모델상에서 발치가 필요한 치아를 제거한 후 열중합 acrylic resin을 이용하여 발치 후 폭경과 높이의 변화 를 측정하기 위하여 인접치아의 근·원심 치아를 최소한 1 개씩 포함하여 스텐트를 제작하였다. 발치 후 예상되는 협·설, 근·원 심벽 부근에 카바이드 버를 이용하여 구멍을 뚫어 재현성 있는 탐침 참고점을 만들었다(Fig. 5A)[19]. 스텐트의 치관 부위에서 탐침이 닿는 부위까지를 $\mathrm{H}$ 로, 발치와의 중심부에 협설측의 너 비를 W로 나타내었다(Fig. 5B, C). 발치 직후, 상피하 결합조직 을 이용한 치조제 보존술 직후, 1 주, 2 주, 3 주, 4 주, 8 주, 12 주에 근심, 원심, 협측, 구개측의 $\mathrm{H}$ 와 협·설측 너비인 $\mathrm{W}$ 를 측정하였 다.

\section{술 후 관리}

모든 환자에게 통상적으로 amocra $375 \mathrm{mg}$ (Amocla 250 mg/125 mg, Amoxacillin $250 \mathrm{mg} /$ Clavulanate K 125 mg Tab), etodin (Etodin $200 \mathrm{mg}$ ), stillen (Stillen 60 mg, Artemisia asiatica ethanol ext. $60 \mathrm{mg}$ )을 삼 일 동안, 하루 세 번 복용하도록 하였고, 통증이 계속적으로 존재할 때에는 자가 통증조절법[20]을 시행하여 etodin을 추가적으로 복용, 최대 복 용량이 하루 6 알을 초과하지 못하게 하였다. 환자분 내원 시마 

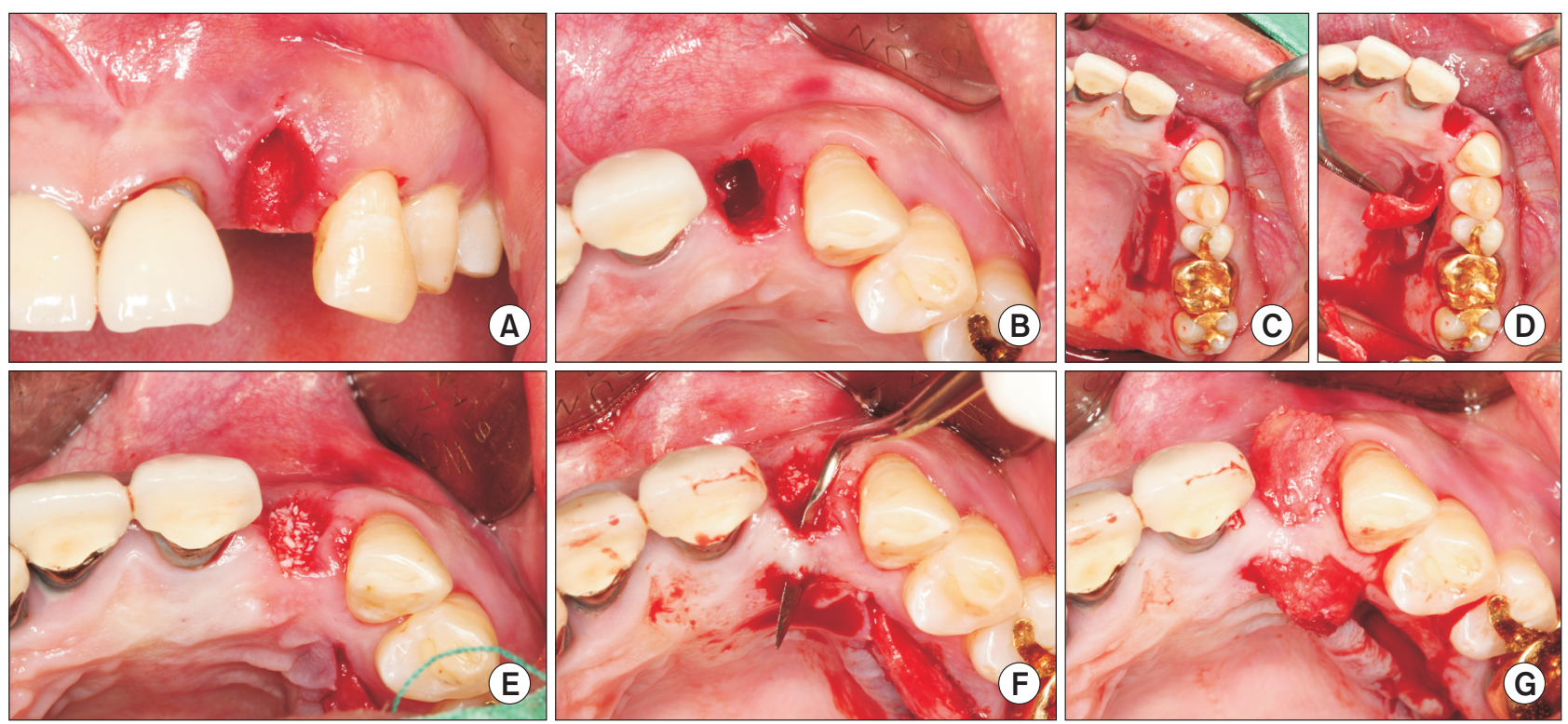

Fig. 4. Surgical process of patient 1. (A) Buccal intraoral view of \#22 after atraumatic extraction using periotome. (B) Occlusal intraoral view of \#22 after atraumatic extraction. (C) Subepithelial connective tissue harvested by epithelium elevation and partial thickness flap. (D) Pedicle graft harvested from \#26 mesial to \#22 distal side. (E) Bone graft (Bio-Oss) on extraction socket. (F) Tunneling conducted on \#22 palatal area by using orban knife. (G) Insertion of pedicle graft into the tunnel. The buccal gingiva was undermined to allow the graft at $3 \mathrm{~mm}$ below the buccal gingiva. And the graft was sutured using cross-mattress and interrupted suture in case of need. Palatal donor site was sutured using cross-mattress suture and interrupted suture.
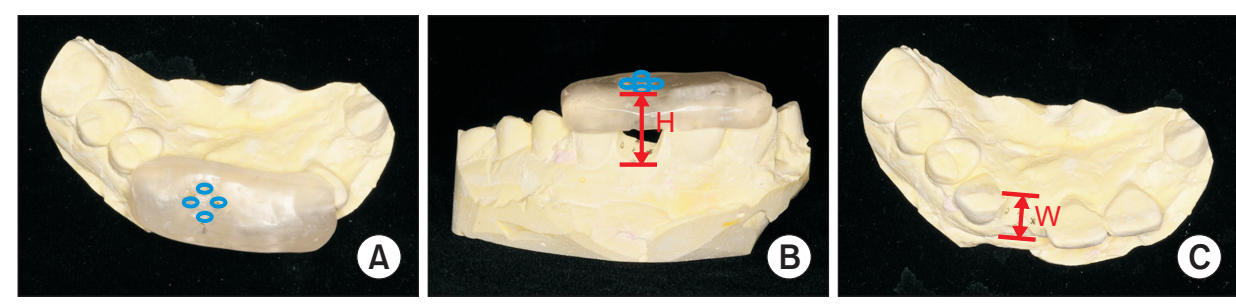

Fig. 5. Fabrication of stent and how to measure the height and width of alveolar ridge on patient 1. (A) Retrievable probing reference points were made using bur at the mesial, distal, buccal and lingual walls of predicted post-extraction socket. (B) Vertical height is a distance from the reference point of stent to the gingiva. and width is the widest distance of bucco-lingual side. (C) Width is the widest distance of bucco-lingual side of alveolar ridge.

다 visualized analogue scale (VAS)를 0-10까지 수치 중 표현 하도록 하였고, 추가적으로 복용한 알약 개수를 파악하였다.

또한 발치 부위의 심미성 향상과 인접치의 기울어짐을 방지 하기 위해 술식 4주 이후 해당 부위 flipper를 제작하였으며, 술 부의 연조직이 눌리지 않도록 디자인하였다.

\section{결 과}

수술 부위는 염증 소견 없이 발치와가 치유되었으며, 다른 부 위와 조화로운 색조를 유지하였다. 환자 1에서 1주, 2 주, 3 주, 4 주, 8 주에 걸쳐서 협측 연조직 치유 상태를 관찰한 결과 4주경
에 완전한 연조직의 치유양상을 보였고 이는 8 주 이후에도 지속 되었다(Fig. 6). 세 명 환자 모두 수술 후 1주차에 수술 부위에 치 은 부종이 관찰되며, 점차 신생 혈관이 형성되어 조직재생이 일 어났으며 부피변화도 안정화되었다(Fig. 7).

세 명 환자 모두에서 스텐트의 수치값 변화를 1 주, 2 주, 3 주, 4 주, 8 주, 12 주에 걸쳐 측정한 결과, 그 변화들은 다음과 같다. $\mathrm{H}$ 는 스텐트의 치관 부위에서 탐침이 닿는 부위까지를 의미하므 로, 값이 커질수록 치조제 높이가 감소함을 의미, $\mathrm{W}$ 는 전체 너 비를 의미하므로 적어질수록 치조제 너비가 감소함을 의미한 다. Baseline과 12주차의 높이와 너비의 변화량은 다음과 같다 (Table 1). 발치 직후와 치조제 보존술 12 주 후를 비교하면 협 

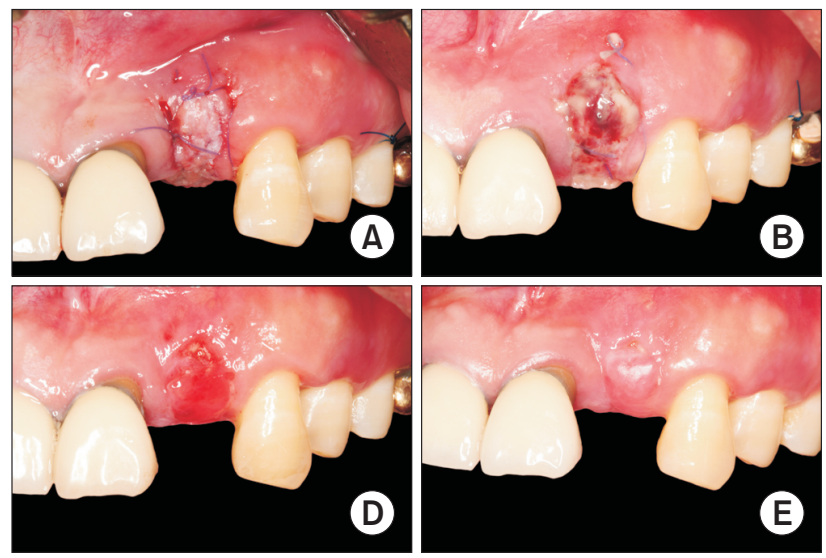

B
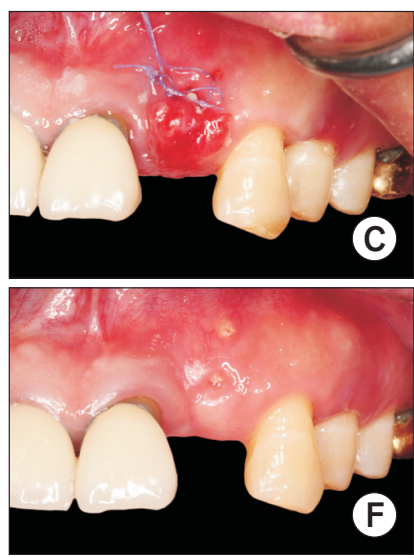

Fig. 6. Changes of soft tissue of patient 1 for 8 weeks. (A) Buccal intraoral view of \#22 after cross-mattress and interrupted suture. (B) A 1 week after operation. (C) A 2 weeks postoperation. (D) A 3 weeks postoperation, anastomosed blood vessels. (E) A 4 weeks postoperation. (F) A 8 weeks postoperation, color and texture of pedicle graft in harmony with adjacent tissue.
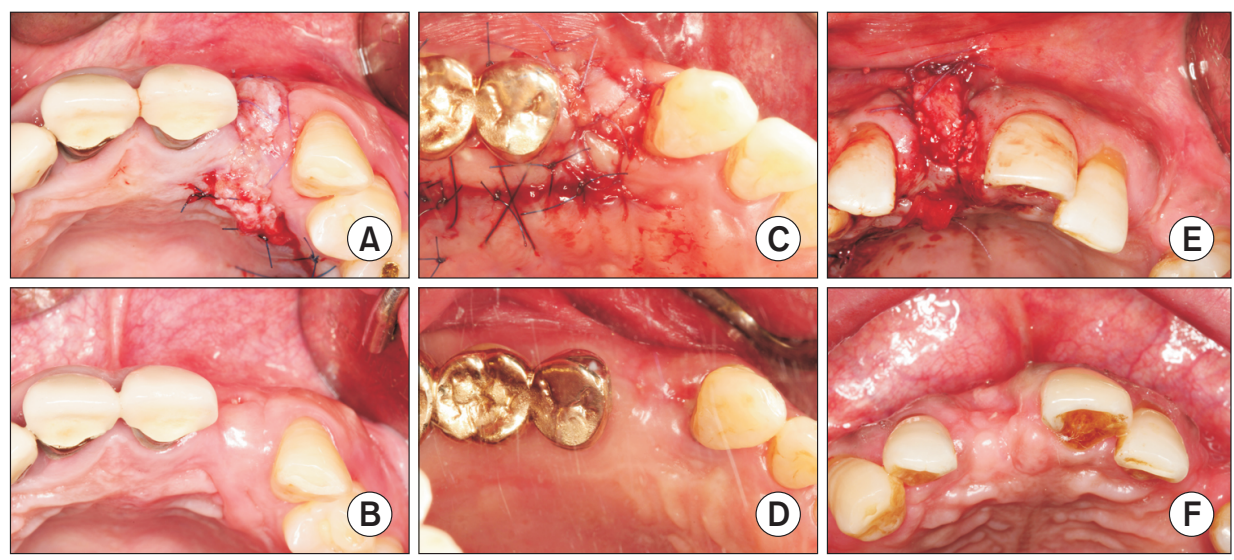

Fig. 7. Healing state of the patients on 8 weeks after surgery. (A, B) Occlusal views of postoperation. (A) and 8 weeks postoperation. (B) of patient 1. (C, D) Occlusal views of postoperation. (C) and 8 weeks postoperation. (D) of patient 2 . (E, F) Occlusal views of postoperation. (E) and 8 weeks postoperation. (F) of patient 3.
Table 1. Changes of height and width of alveolar ridge between 0 and 12 weeks

\begin{tabular}{lcccc}
\hline \multicolumn{1}{c}{ Location } & Patient I & Patient II & Patient III & Mean \\
\hline Height $(\mathrm{mm})$ & & & & \\
Buccal & -2.0 & 0.0 & -1.0 & -1.0 \\
Palatal & 0.0 & -1.0 & -1.0 & -0.7 \\
Mesial & -1.0 & 0.0 & -1.0 & -0.7 \\
distal & 0.0 & -1.0 & 0.0 & -0.3 \\
Width (mm) & 0.5 & 1.5 & 0.0 & 0.7
\end{tabular}

Vertical height is a distance from the reference point of stent to the gingiva and width is the widest distance of bucco-lingual side. Patient I showed the increase of height on buccal and mesial side, $2 \mathrm{~mm}$ and $1 \mathrm{~mm}$, respectively. Patient II showed the increase of height on palatal and distal side, $1 \mathrm{~mm}$ and $1 \mathrm{~mm}$, respectively. And patient III showed the increase of height on buccal, palatal and mesial side, $1 \mathrm{~mm}$ respectively. The mean values of increased height were $1 \mathrm{~mm}$ on buccal, $0.7 \mathrm{~mm}$ on palatal and mesial, $0.3 \mathrm{~mm}$ on distal side. The increased value of width was $0.5,1.5$, and $0 \mathrm{~mm}$ on each patient I-III, so the mean value was $0.7 \mathrm{~mm}$.
측골에서는 환자 1 에서는 협측 $2 \mathrm{~mm}$, 구개측 $0 \mathrm{~mm}$, 근심측 1 $\mathrm{mm}$, 그리고 원심측 $0 \mathrm{~mm}$ 증가되었으며, 환자 2에서는 협측 과 근심측은 발치 전 상태를 그대로 유지하였으나 구개측과 원 심측은 $1 \mathrm{~mm}$ 정도의 증대가 이루어졌다. 또한 환자 3 에서는 협 측, 구개측, 근심측은 $1 \mathrm{~mm}$ 증가하였으나 원심측에는 변화가 없었다. 각 경우에 Elian 등[16]의 분류 중 type 2, 3 정도로 협 측골 소실이 심했지만, 높이가 증대되거나 유지됨을 관찰할 수 있었다. 환자 1,2 에서 너비는 각각 $0.5,1.5 \mathrm{~mm}$ 로 증가하였으 며, 환자 3 에서는 $0 \mathrm{~mm}$ 로 발치 전 상태를 그대로 유지하였다. 세 명 환자에서 평균적으로 협측 $1 \mathrm{~mm}$, 구개측 $0.7 \mathrm{~mm}$, 근심 측 $0.7 \mathrm{~mm}$, 원심측 $0.3 \mathrm{~mm}$ 증가했으며, 너비는 $0.7 \mathrm{~mm}$ 증가 하였다.

VAS 평가에서 환자들은 부은 느낌이나 팩으로 인한 발음의 불편감을 호소하며 2주까지는 10점 만점에 최대 3점을 나타내 었으며, 3 주째에는 최대 1점으로 표현하였으며, 그 후 불편감을 0점으로 표현하였다. 자가통증조절법을 이용하여 평가한 결과 통상적인 3일의 약 복용기간 동안 추가적으로 etodin을 복용한 환자는 없었다(Table 2). 
Table 2. VAS and self-medication with analgesics during 12 weeks

\begin{tabular}{|c|c|c|c|c|c|c|}
\hline \multirow{2}{*}{ Period } & \multicolumn{2}{|r|}{ Patient I } & \multicolumn{2}{|r|}{ Patient II } & \multicolumn{2}{|r|}{ Patient III } \\
\hline & VAS & $\begin{array}{l}\text { Additional medication } \\
\text { (each) }\end{array}$ & VAS & $\begin{array}{l}\text { Additional medication } \\
\text { (each) }\end{array}$ & VAS & $\begin{array}{l}\text { Additional medication } \\
\text { (each) }\end{array}$ \\
\hline $0 \mathrm{~d}^{\mathrm{a}}$ & 3 & 0 & 0 & 0 & 3 & 0 \\
\hline $1 \mathrm{wk}$ & 3 & 0 & 0 & 0 & 0 & 0 \\
\hline $2 \mathrm{wk}$ & 1 & 0 & 0 & 0 & 0 & 0 \\
\hline $3 \mathrm{wk}$ & 1 & 0 & 0 & 0 & 0 & 0 \\
\hline $4 \mathrm{wk}$ & 0 & 0 & 0 & 0 & 0 & 0 \\
\hline $8 \mathrm{wk}$ & 0 & 0 & 0 & 0 & 0 & 0 \\
\hline $12 \mathrm{wk}$ & 0 & 0 & 0 & 0 & 0 & 0 \\
\hline
\end{tabular}

VAS, visualized analogue scale.

The tendency of VAS reporting gradually decreased and no VAS was reported after 4 weeks. Patients self-managed their pain and controlled the consumption of drugs (self-medication with analgesics), and did not take any additional medication other than the routinely prescribed 3 times a day medicine. All patients complained of discomfort such as difficulty in pronunciation and swelling, but no pain.

${ }^{a}$ On the day of surgery.

\section{고 찰}

발치와 치유과정은 하방골의 체적변화와 주변 연조직 구조적 변화를 가져오므로, 발치 시 치조제 보존술을 시행하면 골소실 을 줄이고 발치 후 재건 가능성을 증가시킨다. 발치와의 신생 골 은 발치 후 치조골에 남은 치주인대세포가 발치와 내로 이주하 여 조골세포로 분화되거나, 인접 치조골 내에 조골세포가 직접 이주해오거나 미분화 중배엽세포가 이주하여 조골세포로 분화 하여 형성하는 것으로 알려져 있다. 또한 치조제 보존술은 인접 연조직 높이를 유지하고, 임플란트 식립 시 연조직의 좋은 체적 을 생성하여 임플란트 술식을 단순화하며 심미적인 결과를 증 진시킨다고 보고되었다[4]. 치조제 보존술 시 치유 기간 동안 이 식재를 보존하기 위해 일차피개가 필요하며, 완전한 일차피개 의 성공은 치조제 보존술의 성공률을 증가시킨다. 피개된 판막 의 미세움직임이나 불충분한 혈류, 느린 재혈관화 등은 골증대 술이나 치조제 보존술의 실패로 이어질 수 있다[21]. 일차피개 를 위해 자가조직 이식술이나 막을 사용하는 방법이 있으나 이 번 연구에서는 Romanas 등[15]에 따라 상피하 결체조직을 터 널을 이용하여 일차피개를 시도하였다.

치조제 보존술은 발치 시점에 존재하는 치조제 부피를 유지 하기 위해 시행하며, 치조제 증대술은 발치 시점의 골격을 넘도 록 치조제 부피를 증가시키기 위해 시행한다[22]. 이 연구에서 는 Elian 등[16]의 분류 type 2, 3 환자에서 발치 후 연조직, 경 조직이 부족하여 발치 시 골유도재생술을 시행한다면 일차피개 가 힘들다고 판단하여 치조제 보존술을 시행하기로 치료계획을
세웠다. Zubillaga 등[23]은 현존하는 치조정 수준까지 이식재 를 채울 것을 주장하고, Simon 등[24]은 골이식량이 클수록 치 유된 후 총 증대량이 커지므로 발치와를 초과하여 골이식할 것 을 주장했으나, 이 연구에서는 연조직 피개량과 일차피개를 고 려하여 발치와 내부를 채우는 것으로 시행하였다.

Bio-Oss을 사용 시 흡수율이 낮아 수직적 골소실량이 적 으며 $[7,22]$, 동종골이식, 합성골이식, 자연치유와 비교 시 이 종골이식에서 가장 적은 골소실이 관찰되었다고 보고되었다. Jambhekar 등[25]의 기존 연구에 따라 이번 연구에서는 BioOss를 사용하여, 1 주, 2주, 3주, 4주, 8주, 12 주 동안의 연조직 변화를 살폈다. 1-3주 동안 생착 과정이 이루어지며 조직 부종 도 점점 감소되었다. 그 후 5-8주까지의 변화나 9-12주까지의 변화는 크지 않았다.

Aimetti 등[19]이 자발적 치유 시 발치 3개월 후 치조제의 높 이는 $1.2 \mathrm{~mm}$, 너비는 $3.2 \mathrm{~mm}$ 가량 감소하였으나 치조제 보존 술 후에는 유지되거나 증가함을 관찰할 수 있었다. 또한 Jung 등 [7]의 연구에서 발치 후 처치를 하지 않은 대조군에서 협측, 구 개측 골소실이 $0.5,0.6 \mathrm{~mm}$ 를 보였지만, Bio-Oss과 Mucograft (Geistlich Pharma AG)를 시행한 군은 각각 $0,0.4 \mathrm{~mm}$ 의 골소 실을 보였다. 또한 Bio-Oss과 유리치은이식술을 함께 시행한 군 에서는 차례로 $1.2,0.3 \mathrm{~mm}$ 의 증대가 관찰되어 유리치은이식술 을 시행한 경우 막만을 사용한 경우에 비해 치조제 보존술의 효 과가 더 컸음을 알 수 있었다. 이번 연구에서는 $1.0,0.7 \mathrm{~mm}$ 정 도로 높이 변화는 이전에 유리치은이식술을 시행한 경우와 유 사함을 알 수 있었다. 
이번 연구에서 치조제 너비 변화는 환자 별로 $0.5,1.5,0 \mathrm{~mm}$ 의 증대가 이루어졌다. Aimetti 등[19]의 연구에서 발치 후 자 발적 치유 시 치조제의 너비가 $3.2 \mathrm{~mm}$ 감소가 이루어진 수치 와 대조적이다. 마찬가지로 Jung 등[7]도 자발적 치유에서 치조 제 너비의 $3.3 \mathrm{~mm}$ 감소를 보였으며, Bio-Oss과 Mucograft군 이 $1.2 \mathrm{~mm}$ 감소, Bio-Oss와 유리치은이식술을 시행한 경우 1.4 $\mathrm{mm}$ 의 감소를 보여 자발적 치유 시보다 너비 감소가 더 적다고 보고되었다. 터널을 통한 유경-상피하 결체조직 이식술을 이용 한 이번 연구에서는 너비는 그대로 유지되거나 약 $1.5 \mathrm{~mm}$ 의 증 대를 보여, 자연 치유되는 경우나 다른 유리치은이식술을 한 경 우보다 더 높게 나타났다. 이는 유경조직을 통해 혈액 공급이 이 루어져 치주제 흡수율이 적었을 가능성 때문으로 보이나 다른 실험 연구에 비해 기간이 짧은 한계를 가진다.

그 동안 다양한 치조제 보존술에 관해 직접적인 비교 고찰을 한 연구는 많이 이루어지지 않았다. Iasella 등[26]의 연구에서 발치 후 자연치유 시 연조직 두께는 6개월 후 0.4-0.5 mm 증진 이 일어났지만, 이식재로 인해 혈류 공급이 방해 받았기 때문에 이식한 실험군에서는 오히려 감소를 관찰되었다고 보고하고 있 다. 또한 Tan 등[3]은 경조직과 연조직이 6 개월 후 감소된 양이 경조직만 감소된 양보다 더 크다고 보고했다. 이번 연구에서도 12 주 동안의 추적 기간 동안 stent를 이용하여 치은을 포함한 측정한 결과 높이와 너비의 증대가 이루어졌으며, Iasella 등[26] 과 Tan 등[3]의 논문에 따라 골이식술 이후 연조직이 감소함을 고려했을 때 경조직 증대가 이루어짐을 유추해 볼 수 있다. 하지 만 정확한 측정을 위해 추후 re-entry 수술이 필요하다.

환자중심평가를 위해 VAS 지수와 통증자가 조절법을 이용하 여 진행하였다. $\mathrm{VAS}$ 지수는 1 주 후 10 점 만점에 평균 2 점을 보 였으며 점차 감소하였다. 환자들은 주로 통증보다는 치주포대 로 인한 발음의 어려움, 부은 느낌 등의 불편감을 호소했으며, 4 주가 지난 후에는 불편감을 보고하지 않았다. 통증자가조절법 에서도 통상적으로 처방된 3일치 하루 세 번 복용하는 약을 제 외하고 추가적으로 복용한 환자는 없었으며 환자 반응평가에서 도 통증은 크지 않았다고 진술하였다. 유경조직이식술을 통해 혈액 공급이 이루어지고, 터널을 통해 안정성이 유지되기 때문 으로 생각된다.

환자 2의 경우 치은퇴축이 관찰되었는데, 경조직의 부족은 치 아 주변의 인접면을 채우는 것을 위태롭게 만들기 때문에[27], 지지 경조직이 부족하여 약간의 치은퇴축이 야기된 것으로 여 겨진다.

이 연구에서는 스텐트를 통해 연조직 변화만을 살폈다는 한 계를 갖는다. 임플란트를 식립 시 re-entry 수술이 계획되어 있 어서 관찰 기간 동안에는 골충전에 대한 측정을 시행하지 못하 였다. 추후 임플란트를 식립할 때 re-entry를 통해 경조직 측정
과 골표본 채취를 통해 조직학적 분석이 추가적으로 필요할 것 으로 생각된다.

결론적으로 터널을 이용한 유경조직 이식술은 혈행 공급과 안정성을 높여 치조제 보존술에 시행되었을 경우, 치조제의 높 이와 너비 유지로 연조직 증대술이 가능하도록 하였다. 술기 민 감성을 가지는 단점이 있지만, 치유양상이 양호하며 상악 심미 영역의 발치와 관리에 추천이 되는 술식으로 생각된다.

\section{CONFLICTS OF INTEREST}

The authors declare that they have no competing interests.

\section{ORCID}

\author{
Ju-Eun Bae \\ https://orcid.org/0000-0002-3572-4223 \\ Yong-Gun Kim \\ https://orcid.org/0000-0002-2793-7667 \\ Jin-Woo Park \\ https://orcid.org/0000-0002-6632-023X \\ Jae-Mok Lee \\ https://orcid.org/0000-0002-0291-6114 \\ Jo-Young Suh \\ https://orcid.org/0000-0002-3515-3854
}

\section{REFERENCES}

1. Pietrokovski J, Massler M. Alveolar ridge resorption following tooth extraction. J Prosthet Dent 1967;17:21-27. doi: 10.1016/0022-3913(67)90046-7.

2. Lang NP, Pun L, Lau KY, Li KY, Wong MC. A systematic review on survival and success rates of implants placed immediately into fresh extraction sockets after at least 1 year. Clin Oral Implants Res 2012;23 Suppl 5:39-66. doi: 10.1111/j.1600-0501.2011.02372.x.

3. Tan WL, Wong TL, Wong MC, Lang NP. A systematic review of post-extractional alveolar hard and soft tissue dimensional changes in humans. Clin Oral Implants Res 2012;23 Suppl 5:1-21. doi: 10.1111/j.1600-0501. 2011.02375.x.

4. Wang HL, Tsao YP. Mineralized bone allograft-plug socket augmentation: rationale and technique. Implant Dent 2007;16:33-41. doi: 10.1097/ID.0b013e318031ece6.

5. Lekovic V, Kenney EB, Weinlaender M, Han T, Klokkevold P, Nedic M, Orsini M. A bone regenerative approach to alveolar ridge maintenance following tooth extraction. 
Report of 10 cases. J Periodontol 1997;68:563-570. doi: 10.1902/jop.1997.68.6.563.

6. Lekovic V, Camargo PM, Klokkevold PR, Weinlaender M, Kenney EB, Dimitrijevic B, Nedic M. Preservation of alveolar bone in extraction sockets using bioabsorbable membranes. J Periodontol 1998;69:1044-1049. doi: 10.1902/jop.1998.69.9.1044.

7. Jung RE, Philipp A, Annen BM, Signorelli L, Thoma DS, Hämmerle CH, Attin T, Schmidlin P. Radiographic evaluation of different techniques for ridge preservation after tooth extraction: a randomized controlled clinical trial. J Clin Periodontol 2013;40:90-98. doi: 10.1111/jcpe. 12027.

8. Oghli AA, Steveling H. Ridge preservation following tooth extraction: a comparison between atraumatic extraction and socket seal surgery. Quintessence Int 2010;41:605609.

9. Koh RU, Oh TJ, Rudek I, Neiva GF, Misch CE, Rothman ED, Wang HL. Hard and soft tissue changes after crestal and subcrestal immediate implant placement. J Periodontol 2011;82:1112-1120. doi: 10.1902/jop.2011.100541.

10. Nemcovsky CE, Artzi Z, Moses O. Rotated palatal flap in immediate implant procedures. Clinical evaluation of 26 consecutive cases. Clin Oral Implants Res 2000;11:83-90. doi: 10.1034/j.1600-0501.2000.011001083.x.

11. Goldstein M, Boyan BD, Schwartz Z. The palatal advanced flap: a pedicle flap for primary coverage of immediately placed implants. Clin Oral Implants Res 2002;13:644-650. doi: 10.1034/j.1600-0501.2002.130611.x.

12. Khoury F, Happe A. The palatal subepithelial connective tissue flap method for soft tissue management to cover maxillary defects: a clinical report. Int J Oral Maxillofac Implants 2000;15:415-418.

13. Matthews DP. The pediculated connective tissue graft: a novel approach for the "blown-out" site in the esthetic zone. Compend Contin Educ Dent 2008;29:350-352, 354, 356-357.

14. Tal H. Autogenous masticatory mucosal grafts in extraction socket seal procedures: a comparison between sockets grafted with demineralized freeze-dried bone and deproteinized bovine bone mineral. Clin Oral Implants Res 1999;10:289-296. doi: 10.1034/j.1600-0501.1999.100405.x.

15. Romanos AH, Geurs NC, Abou-Arraj RV. Pedicle connective tissue graft with novel palatal tunneling. Clin Adv Periodontic 2013;3:191-198. doi: 10.1902/cap. 2013.120125.

16. Elian N, Cho SC, Froum S, Smith RB, Tarnow DP. A simplified socket classification and repair technique. Pract Proced Aesthet Dent 2007;19:99-104.

17. Claffey N, Shanley D. Relationship of gingival thickness and bleeding to loss of probing attachment in shallow sites following nonsurgical periodontal therapy. J Clin Periodontol 1986;13:654-657. doi: 10.1111/j.1600-051X. 1986.tb00861.x.

18. Liu CL, Weisgold AS. Connective tissue graft: a classification for incision design from the palatal site and clinical case reports. Int J Periodontics Restorative Dent 2002;22:373379. doi: $10.11607 /$ prd.00.0475.

19. Aimetti M, Romano F, Griga FB, Godio L. Clinical and histologic healing of human extraction sockets filled with calcium sulfate. Int J Oral Maxillofac Implants 2009;24: 902-909.

20. Mittal P, Chan OY, Kanneppady SK, Verma RK, Hasan SS. Association between beliefs about medicines and selfmedication with analgesics among patients with dental pain. PLoS One 2018;13:e0201776. doi: 10.1371/journal. pone. 0201776.

21. Vance GS, Greenwell H, Miller RL, Hill M, Johnston H, Scheetz JP. Comparison of an allograft in an experimental putty carrier and a bovine-derived xenograft used in ridge preservation: a clinical and histologic study in humans. Int J Oral Maxillofac Implants 2004;19:491-497.

22. Hämmerle CH, Araújo MG, Simion M; Osteology Consensus Group 2011. Evidence-based knowledge on the biology and treatment of extraction sockets. Clin Oral Implants Res 2012;23 Suppl 5:80-82. doi: 10.1111/j.1600-0501.2011. 02370.x.

23. Zubillaga G, Von Hagen S, Simon BI, Deasy MJ. Changes in alveolar bone height and width following post-extraction ridge augmentation using a fixed bioabsorbable membrane and demineralized freeze-dried bone osteoinductive graft. J Periodontol 2003;74:965-975. doi: 10.1902/jop. 2003.74.7.965.

24. Simon BI, Von Hagen S, Deasy MJ, Faldu M, Resnansky D. Changes in alveolar bone height and width following ridge augmentation using bone graft and membranes. J Periodontol 2000;71:1774-1791. doi: 10.1902/jop.2000. 71.11.1774.

25. Jambhekar S, Kernen F, Bidra AS. Clinical and histologic outcomes of socket grafting after flapless tooth extraction: a systematic review of randomized controlled clinical trials. J Prosthet Dent 2015;113:371-382. doi: 10.1016/j. prosdent.2014.12.009.

26. Iasella JM, Greenwell H, Miller RL, Hill M, Drisko C, Bohra AA, Scheetz JP. Ridge preservation with freeze-dried bone allograft and a collagen membrane compared to extraction alone for implant site development: a clinical and histologic study in humans. J Periodontol 2003;74:990999. doi: 10.1902/jop.2003.74.7.990.

27. Bouchard P, Malet J, Borghetti A. Decision-making in aesthetics: root coverage revisited. Periodontol 2000 2001; 27:97-120. doi: 10.1034/j.1600-0757.2001.027001097.x. 